\title{
A generic process template for continuous pharmaceutical production
}

Singh, Ravendra; Rozada-Sanches, Raquel; Dean, William ; Perkins, Jacob; Muller, Frans; Godfrey, Andy; Gernaey, Krist; Gani, Rafiqul; Woodley, John

\section{Published in:}

Proceedings of the 11th International Symposium on Process Systems Engineering

Link to article, DOI:

10.1016/B978-0-444-59507-2.50135-9

Publication date:

2012

Document Version

Publisher's PDF, also known as Version of record

Link back to DTU Orbit

Citation (APA):

Singh, R., Rozada-Sanches, R., Dean, W., Perkins, J., Muller, F., Godfrey, A., Gernaey, K., Gani, R., \& Woodley, J. (2012). A generic process template for continuous pharmaceutical production. In I. A. Karimi, \& R. Srinivasan (Eds.), Proceedings of the 11th International Symposium on Process Systems Engineering (pp. 715719). Elsevier. Computer Aided Chemical Engineering Vol. 31 https://doi.org/10.1016/B978-0-444-595072.50135-9

\section{General rights}

Copyright and moral rights for the publications made accessible in the public portal are retained by the authors and/or other copyright owners and it is a condition of accessing publications that users recognise and abide by the legal requirements associated with these rights.

- Users may download and print one copy of any publication from the public portal for the purpose of private study or research.

- You may not further distribute the material or use it for any profit-making activity or commercial gain

- You may freely distribute the URL identifying the publication in the public portal 
A generic process template for continuous pharmaceutical production Ravendra Singh ${ }^{a, b}$, Raquel Rozada-Sanchez ${ }^{c}$, William Dean ${ }^{c}$, Jacob Perkins $^{c}$, Frans Muller $^{c}$, Andy Godfrey ${ }^{c}$, Krist V. Gernaey ${ }^{a}$, Rafiqul Gani $^{b}$ and John M. Woodley ${ }^{a^{*}}$

${ }^{a}$ PROCESS, Department of Chemical and Biochemical Engineering, Technical University of Denmark, DK-2800 Lyngby, Denmark ${ }^{b}$ CAPEC, Department of Chemical and Biochemical Engineering, Technical University of Denmark, DK-2800 Lyngby, Denmark ${ }^{c}$ AstraZeneca Limited, Charter Way, Silk Road Business Park, Macclesfield, Cheshire SK10 2NA, UK

In most of the manufacturing industry (and in particular in the pharmaceutical industry), one of the prime objectives is to be fast in the development of new processes, such that it is possible to be first to launch new products on the market. Identification of an effective and safe pharmaceutical product is based on success in clinical trials. Often, several candidate compounds targeting the same disease area are tested in order to identify efficacious products. This involves the manufacture of small quantities of compounds in early delivery campaigns. Of these candidates only a few will be successful such that further development is required to scale-up the process. Conventionally, for each product candidate a unique process needs to be developed. However, the development of a specific process for each product candidate is costly in terms of time and resources. Therefore, a generic process template is needed that can be adapted for production of a series of similar products for the early delivery campaigns, resulting in a significant reduction of time, early manufacturing cost and resource consumption. A generic process template can be defined as a standard process format able to be adapted for a series of similar substrates.

In the work reported here, a generic continuous process template for pharmaceutical production involving nitro reduction has been developed. The developed process template can be adapted for a series of nitro compounds (substrates). To assist in adoption of different substrates, a systematic substrate adoption methodology (SAM) is also presented. The generic process template together with the SAM provides a flexibility similar to batch processes as well as an efficiency similar to continuous processes. It also reduces inventory for a safer operation (from 50 to $100 \mathrm{~L}$ in batch to 3 to $5 \mathrm{~L}$ in continuous process). The generic process template will potentially reduce the process development time and therefore supports shortening time to market for a given compound. In addition to SAM, other methods and tools that support the manufacturing concept proposed in this work contribute to making it flexible and fast to implement (e.g. a graphical tool for determining a suitable operating window and property prediction methods and tools).

The objective of this presentation is two-fold: First to highlight the value of a generic process template and the associated methods and tools, and second to demonstrate its application using a pharmaceutical case study involving a nitro reduction.

\section{*Presenting author (John M. Woodley)}

